\title{
THE NONPROTEIN NITROGENOUS CONSTITUENTS OF THE BLOOD AND THE PHENOLSULPHONE- PHTHALEIN TEST IN CHILDREN *
}

\author{
JEROME S. LEOPOLD, M.D. \\ AND \\ ADOLPH BERNHARD, B.S. \\ NEW YORK
}

During the past few years the determination of the nitrogenous constituents of the blood has been rendered much more simple and accurate by the improved methods of Folin and Denis, ${ }^{1}$ Marshall and Davis, ${ }^{2}$ Van Slyke and Cullen, ${ }^{3}$ Benedict, ${ }^{4}$ and others. Previous to the studies of Folin and his co-workers very little, if any, dependence could be placed on the quantitative analysis of the blood for its nonprotein nitrogenous constituents.

BLOOD IN ADULTS

The results of many investigations of the chemistry of the blood have recently appeared in the literature, and, as a result, standard figures for adults are now available. ${ }^{5}$

The total nonprotein nitrogen of the blood has been demonstrated to be the index of the efficiency of the kidney in removing waste nitrogenous products circulating in the blood. It has been conclusively shown that the total nonprotein nitrogen is increased in the blood in certain forms of kidney disease, and that a definite diagnosis of impaired renal function can be made by this examination of the blood. Normally the total nonprotein nitrogen varies between 25 and $40 \mathrm{mg}$. per 100 c.c. of blood. In cases of severe chronic nephritis with uremic

\footnotetext{
* Submitted for publication, March 15, 1916.

* From the A. Jacobi Division for Children and the Pathological Department of the German Hospital, New York City.

1. Folin and Denis: Jour. Biol. Chem., 1912, xi, 527; xiii, 469; 1913, xiv, 29; 1914, xvii, 463. Frothingham, Fitz, Folin and Denis: Arch. Int. Med., 1913, xii, 245 . ,

2. Marshall and Davis: Jour. Biol. Chem., 1913, xiv, 283; xv, 487; 1914, xviii, 53.

3. Van Slyke and Cullen: Jour. Biol. Chem., 1914, xix, 211.

4. Benedict: Jour. Biol. Chem., 1915, xx, 629.

5. Farr and Austin: Jour. Exper. Med., 1913, xviii, 228. Farr and Krumbhaar: Jour Am. Med. Assn., 1914, 1xiii, 2214. Foster and Davis: Am. Jour. Med. Sc., 1916, cli, 49. Foster: Arch. Int. Med., 1914, xiii, 452; 1915, xv, 356. Frothingham, Fitz, Folin and Denis: Arch. Int. Med., 1913, xii, 245. Frothingham and Smillie: Arch. Int. Med., 1914, xiv, 541. Mrclean and Selling: Jour. Biol. Chem., 1914, xix, 31. Meyers and Fine: Proc. Soc. Exper. Biol. and Med., 1913, xi, 132; Jour. Biol. Chem., 1915, xx, 391.
} 
nianifestations the nonprotein nitrogen, according to several investigators, may amount to $300 \mathrm{mg}$., or even more. Furthermore, it has been shown that cases of nephritis having figures above $60 \mathrm{mg}$. usually end fatally.

The virea nitrogen of the blood amounts to about 50 per cent. of the total nonprotein nitrogen. Most investigators give as normal figures 12 to $20 \mathrm{mg}$. per 100 c.c. of blood. The variations in the urea nitrogen closely parallel the total nonprotein nitrogen.

The normal uric acid content of the blood is from 1 to $2 \mathrm{mg}$. per 100 c.c. It is usually increased in cases of severe nephritis, gout and lead poisoning.

Creatinin was first suggested by Neubauer ${ }^{6}$ as an index of renal function. According to Folin and Denis, ${ }^{1}$ the kidneys remove creatinin from the blood with remarkable ease, and except in cases of extreme retention, the creatinin of the blood remains at the normal level. Normally the blood contains from 1 to $2 \mathrm{mg}$. of creatinin per 100 c.c. Myers and Lough' have demonstrated that a creatinin concentration over $2.5 \mathrm{mg}$. is almost invariably found only when renal involvement exists. Creatinin values from 3 to $5 \mathrm{mg}$. are regarded as decidedly unfavorable from a prognostic point of view, while figures over $5 \mathrm{mg}$. probably indicate an early fatal termination.

\section{BLOOD IN CHILDREN}

Since these newer methods of blood examination have been introduced, very few studies have been made in children. Schlutz and Pettibone $^{8}$ recently reported the results of their examination of the blood for total nonprotein nitrogen and urea in some newly born infants. Tileston and Comfort ${ }^{9}$ have examined the blood of children for total nonprotein nitrogen and urea. The results of these investigators correspond very closely, as far as they go, with figures obtained in adults.

No reports have as yet been made on examinations for uric acid and creatinin in the blood of children. Before any accurate studies, analogous to those made in adults, are possible, the normal figures in children must be definitely established. We therefore determined to examine the blood for total nonprotein nitrogen, urea, uric acid, and creatinin in a series of children free from renal disease to determine if the results obtained corresponded with those found in normal adults. During the investigation a number of cases with renal involvement

6. Neubauer: München. med. Wchnschr., 1914, 1xi, 857.

7. Meyers and Lough: Arch. Int. Med., 1915, xvi, 536.

8. Schlutz and Pettibone: Am. Jour. Dis. Child., 1915, x, 206.

9. Tileston and Comfort: AM. Jour. Dis. Child., 1915, x, 278. 
were examined. These are included in our report; we reserve for a future communication, however, a detailed study devoted to nephritic cases alone.

\section{TECHNIC}

The phenolstulphonephthalcin test was performed in each case by intramuscular injection, according to the method of Rowntree and Geraghty, ${ }^{10}$ and the total amount of the dye-stuff excreted in two hours was determined.

Method of Procuring Blood.-Thirty c.c. were withdrawn under aseptic precautions from a vein at the bend of the elbow into a small glass bottle containing a few crystals of potassium oxalate to prevent clotting. There has been no difficulty in obtaining this amount of blood. Untoward effects were never observed, even in very young children. The blood was taken in the morning before breakfast, about fourteen hours after the last meal.

We have employed, with slight modifications, Folin and Denis' ${ }^{1}$ method for nonprotein nitrogen, Van Slyke and Cullen's ${ }^{3}$ procedure for urea, Benedict's ${ }^{4}$ modification of Folin and Denis' method for uric acid, and Myers and Fine's ${ }^{5},{ }^{\prime}$ modification of Folin's method for creatinin. In our studies the Hellige colorimeter was used.

Nonprotcin Nitrogen.-Into a 50 c.c. volumetric flask, which has been half filled with methyl alcohol, free from acetone, 5 c.c. of blood is pipetteci. This is made up to volume with alcohol, shaken thoroughly, and allowed to stand for two hours. After being filtered into a wide-mouth test tube, from 3 to 4 drops of a saturated alcoholic solution of zinc chlorid are added, and the whole is refiltered. This second filtrate should be clear. Ten c.c., equivalent to 1 c.c. of blood, is placed in a Jena glass test tube (120 by $20 \mathrm{mg}$.), and about $0.4 \mathrm{gm}$. potassium sulphate, 1 drop of 10 per cent. copper sulphate, 1 c.c. of concentrated sulphuric acid, and from 4 to 6 drops of kerosene are added. The test tube is then placed into a beaker of warm water and slowly heated until all the alcohol has been driven off. The tube is removed from the beaker, dried, and heated over a microburner until the fluid is perfectly clear, and, as a rule, colorless. It is then allowed to cool. Five c.c. of distilled water are then added. The tube is placed into one of the cylinders of the aerating apparatus, and connected at once with another aerating cylinder containing 20 c.c. distilled water and 1 drop of concentrated hydrochloric acid. The cylinder containing the tube is opened, 5 c.c. of concentrated sodium hydroxid are added, and it is then immediately closed. The ammonia is aerated for one-half hour. Diluted Nessler's solution is added to the cylinder into which the ammonia has been aerated, the unknown solution is made up to volume and compared in the colorimeter with a standard solution containing $1 \mathrm{mg}$. of nitrogen. From the reading obtained the amount of nitrogen in the unknown is calculated from the tables furnished by Myers and Fine. ${ }^{11}$

Urea.-Into a wide-mouth test tube 2 c.c. of blood are pipetted, and $1 / 10 \mathrm{gm}$. soy bean urease (Arlco-Urease), is added, and about 2 c.c. distilled water. This is incubated for five minutes at $50 \mathrm{C} .(122 \mathrm{~F}$.). The tube is then removed from the incubator. The foaming inhibitor and an equal volume of saturated potassium carbonate are added. The tube is then placed in a cylinder of the aerating apparatus and the ammonia aerated. The nitrogen is calculated as in the nonprotein nitrogen estimation above."

Uric Acid.-Twenty c.c. of blood are pipetted into a 375 c.c. casserole, and five volumes of freshly prepared hundredth-normal acetic acid. The casserole is placed on a water bath, the contents stirred, and heated until coagulation occurs. The casserole is then heated over the open flame and 2 teaspoonfuls of thick alumina cream are added. The sides of the casserole are washed

10. Rowntree and Geraghty: Jour. Pharmacol. and Exper. Ther., 1910, i, 579; Arch. Int. Med., 1912, ix, 284; 1913, xi, 121.

11. Myers and Fine: Essentials of Path. Chem., 1913. 
with hot water and the solution again heated for a few minutes. The solution is then poured through hardened filter paper into a 250 c.c. graduated cylinder. The filtrate should be absolutely clear. The coagulum is washed back into the original casserole with hot water, heated, and refiltered, the same filter paper being used. To the combined filtrates 1 drop of glacial acetic acid is added. The solution is evaporated on the water bath down to about 3 c.c., and transferred to a 15 c.c. conical centrifuge tube. The casserole is flushed out with a little hot water, and the washings added to the tube. The total volume should amount to about 10 c.c. The tube and contents are centrifuged, the supernatant liquid poured off into another centrifuge tube and, when cool, 15 drops of silver magnesia are added. The solution is then thoroughly mixed and placed in the ice box for fifteen minutes. The tube is again centrifuged and the supernatant liquid decanted. The lip of the tube is dried with filter paper. The ammonia is volatilized by suction. To the sediment in the tube is added 1 or 2 drops of 5 per cent. potassium cyanid and 2 c.c. of Folin-Macullum reagent. The solution is transferred to a 50 or 100 c.c. graduated cylinder, and 20 c.c. of saturated sodium carbonate added. The mixture is then diluted to 50 or 100 c.c. with water, depending on the intensity of the color, and compared in the colorimeter with a standard solution containing $1 \mathrm{mg}$. of uric acid. The amount of uric acid present is calculated from the tables. ${ }^{11}$

Creatinin.-Two c.c. of blood are pipetted into a glass centrifuge tube (130 by $12 \mathrm{~mm}$.), and 8 c.c. of distilled water are added. After the corpuscles have been laked, about $1 \mathrm{gm}$. of dry picric acid is added, and the mixture stirred with a glass rod until the whole mass assumes a light yellow color. It is then centrifuged and the supernatant liquid filtered. Two c.c. of the filtrate is placed in the cup of the colorimeter and 0.1 c.c. of 10 per cent. sodium hydroxid is added. The mixture is allowed to stand for ten minutes. It is then compared with a standard solution of creatinin to which the same percentage of sodium hydroxid has been added, and which has been allowed to stand for ten minutes. The amount of creatinin is calculated from the tables of Myers and Fine."

The results of the blood examination in fifty hospital children without any evidence of renal disease are shown in Table 1. In Table 2 are recorded the blood analyses of sixteen children in whom there was demonstrated, at the period of examination, some evidence of renal involvement. The figures represent in milligrams the respective amounts of nonprotein nitrogen, urea, uric acid, and creatinin per 100 c.c. of blood. The phthalein excretion for two hours is given in each case.

\section{DISCUSSION OF TABLE 1: CHILDREN FREE FROM RENAL DISEASE}

Nonprotein Nitrogen.-The nonprotein nitrogen varied between 19 and 40 mg. per 100 c.c. of blood. The average amount in fifty children was $28 \mathrm{mg}$. These figures correspond very closely with the values between 15 and $43 \mathrm{mg}$., as given by Farr and Austin ${ }^{5}$ and some other investigators of adult blood. They are somewhat higher than those found by Folin and Denis (22 to $26 \mathrm{mg}$.). It should be stated, however, that the latter call attention to the fact that, when other than perfectly healthy persons are examined, higher values than from 22 to $26 \mathrm{mg}$. are obtained even though there are no evidences of renal disease. Attention was called to the fact that our observations were made on children who were hospital patients, and this may account for our slightly higher figures. Furthermore, according to Agnew $^{12}$ a nonprotein nitrogen

12. Agnew: Arch. Int. Med., 1914, xiii, 485. 
TABLE 1.-Analyses of the Blood of Children Free from Renal Disease

\begin{tabular}{|c|c|c|c|c|c|c|c|c|c|}
\hline \multirow[b]{2}{*}{ Case } & \multirow[b]{2}{*}{$\begin{array}{l}\text { Age, } \\
\text { Years }\end{array}$} & \multirow[b]{2}{*}{$\operatorname{Sex}^{*}$} & \multirow[b]{2}{*}{$\begin{array}{l}\text { Weight, } \\
\text { Pounds }\end{array}$} & \multicolumn{4}{|c|}{ Blood Analysis } & \multirow[b]{2}{*}{$\begin{array}{c}\text { Phenol- } \\
\text { sul- } \\
\text { phone- } \\
\text { thalefn, } \\
\text { Per } \\
\text { Cent. }\end{array}$} & \multirow[b]{2}{*}{ Diagnosis } \\
\hline & & & & $\begin{array}{c}\text { Non- } \\
\text { protein } \\
\mathbf{N}, \mathbf{M g} \\
\text { per } \\
100 \mathrm{c.c} .\end{array}$ & $\begin{array}{c}\text { Urea } \\
\text { N, } \\
\text { Mg. } \\
\text { per } \\
100 \text { c.c. }\end{array}$ & $\begin{array}{c}\text { Oric } \\
\text { Acid } \\
\text { Mg. } \\
\text { per } \\
100 \text { c.c. }\end{array}$ & $\begin{array}{c}\text { Creat- } \\
\text { inin, } \\
\text { Mg. } \\
\text { per } \\
\text { 100e.c. }\end{array}$ & & \\
\hline 5271 & 12 & q & $681 / 4$ & 37 & 10 & 2.6 & 1.1 & 74 & Postscarlatinal paral- \\
\hline 7563 & 13 & $\sigma^{*}$ & $721 / 2$ & 37 & 12.5 & 2.7 & 1.1 & 66 & Malaria \\
\hline 7334 & 9 & 8 & .. & 26 & 11.5 & 1.8 & 1.1 & 85 & Osteomyelitis of patella \\
\hline 7203 & 7 & $q$ & 49 & 26 & 13 & 1.9 & 1.0 & 66 & Thyroglossal cyst \\
\hline 7967 & 10 & $\sigma^{\circ}$ & .. & 31 & 13 & 0.8 & 0.5 & 92 & Luetic synovitis \\
\hline 7902 & 10 & $\sigma^{\circ}$ & .. & 27 & 11 & 3.1 & 0.8 & 66 & Undescended testicle \\
\hline 7809 & 8 & $q$ & .. & 22 & 10 & 1.1 & 1.0 & 81 & Appendicitis \\
\hline 7989 & 8 & $\sigma^{x}$ & 55 & 20 & 10.5 & 1.3 & 0.6 & 79 & Tuberculosis \\
\hline 7036 & 2 & q & 25 & 30.5 & 10.5 & 1.4 & 0.6 & 58 & Adenites \\
\hline 7986 & 6 & $\sigma^{\prime}$ & 44 & 31.5 & 10.5 & 2.1 & 1.3 & 77 & Cardiac \\
\hline 8148 & 12 & q & 59 & 33 & 16 & 2.3 & 0.9 & 75 & Frost bite \\
\hline 8169 & 12 & q & .. & 26 & 11 & 2.7 & 0.7 & 71 & Appendicitis \\
\hline 8170 & 9 & q & $441 / 2$ & 35 & 21 & 1.3 & 0.8 & 88 & Cardiac \\
\hline 8127 & 8 & $\sigma^{\pi}$ & 51 & 38 & 13 & 1.8 & 0.8 & 76 & Pneumonia, after crisis \\
\hline 8201 & 10 & $\sigma^{\pi}$ & 68 & 40 & 15 & 1.8 & 1.1 & 81 & Neurosis \\
\hline 8244 & 8 & $q$ & 52 & 29.5 & 12.5 & 1.5 & 1.1 & 79 & Appendicitis \\
\hline 8251 & 5 & $\sigma^{2}$ & 37 & 22 & 11 & 1.3 & 1.2 & 77 & Grippe \\
\hline 8367 & 6 & $\sigma^{\prime \prime}$ & 36 & 33 & 12.5 & 1.9 & 0.5 & 85 & Jaundice \\
\hline 7912 & 6 & q & 39 & 30 & 10.5 & 1.9 & 0.5 & 87 & Grippe \\
\hline 2141 & 6 & 9 & 40 & 23 & 8.5 & 1.5 & 1.5 & 80 & Little's disease \\
\hline 7022 & 12 & $\sigma^{\prime}$ & 69 & 31.5 & 10.5 & 2.1 & 2.4 & 81 & Typhoid convalescence \\
\hline 6691 & 9 & $\sigma^{\circ}$ & $6 \overline{5}$ & 31 & 12.5 & 2.1 & 1.5 & $\pi$ & Typhoid convalescence \\
\hline 8533 & 7 & & 42 & 28 & 11 & 2.5 & 2.4 & 96 & Pulmonary tuberculosis \\
\hline 8446 & 5 & $\sigma^{\circ}$ & 38 & 32 & 13 & 3.2 & 2.8 & 65 & Muscular rheumatism \\
\hline 7111 & 12 & ㅇ & 64 & 19 & 10 & 0.8 & 0.8 & 87 & Cardiac \\
\hline 7848 & 7 & & 46 & 20 & 9.5 & 1.8 & 1.1 & 71 & Burn \\
\hline 172 & 6 & q & 44 & 30.5 & 12.5 & 1.9 & 2.2 & 65 & Unresolved pneumonia \\
\hline 197 & 8 & $\sigma^{2}$ & 61 & 27 & 13 & 1.3 & 2.4 & 75 & Chorea \\
\hline 194 & 13 & q & 89 & 27 & 13 & 2.3 & 1.7 & 58 & Rheumatism \\
\hline 157 & 9 & q & 48 & 20 & 8 & 2.4 & 0.9 & 73 & Cardiac \\
\hline 213 & 13 & $q$ & 54 & 26 & 10 & 1.5 & 2.5 & 74 & Incipient tuberculosis \\
\hline 124 & 6 & q & 39 & 26 & 10 & 1.1 & 2.2 & 87 & Cardiac \\
\hline 279 & 5 & $\sigma^{\prime \prime}$ & 47 & 30 & 9 & 2.3 & 4.0 & 74 & $\begin{array}{l}\text { Marked constipation; } \\
\text { Hirschsprung's dis. }\end{array}$ \\
\hline 322 & 14 & & 57 & 26 & 9 & 2.8 & 2.4 & 84 & Appendicitis \\
\hline 385 & 8 & 운 & 55 & 31 & 15 & 1.8 & 2.4 & 76 & Neurosis \\
\hline
\end{tabular}

* $\sigma$ denotes male: $q$, female. 
TABLE 1.-Analyses of the Blood of Children Free from Renal Disease-(Continued)

\begin{tabular}{|c|c|c|c|c|c|c|c|c|c|}
\hline \multirow[b]{2}{*}{ Case } & \multirow[b]{2}{*}{$\begin{array}{l}\text { Age, } \\
\text { Years }\end{array}$} & \multirow[b]{2}{*}{$\operatorname{Sex}^{*}$} & \multirow[b]{2}{*}{$\begin{array}{l}\text { Weight, } \\
\text { Pounds }\end{array}$} & \multicolumn{4}{|c|}{ Blood Analysis } & \multirow[b]{2}{*}{$\begin{array}{c}\text { Phenol- } \\
\text { sul- } \\
\text { phone- } \\
\text { thalein, } \\
\text { Per } \\
\text { Cent. }\end{array}$} & \multirow[b]{2}{*}{ Diagnosis } \\
\hline & & & & $\begin{array}{c}\text { Non- } \\
\text { protein } \\
\mathbf{N}, \mathbf{M g} . \\
\text { per } \\
100 \text { c.c. }\end{array}$ & $\begin{array}{c}\text { Urea } \\
\mathbf{N}, \\
\mathbf{M g} . \\
\text { per } \\
100 \text { c.c. }\end{array}$ & $\begin{array}{l}\text { Uric } \\
\text { Acid } \\
\text { Mg. } \\
\text { per } \\
100 \text { c.c. }\end{array}$ & $\begin{array}{l}\text { Creat- } \\
\text { inin, } \\
\mathbf{M g} . \\
\text { per } \\
100 \text { c.c. }\end{array}$ & & \\
\hline 150 & 5 & $\sigma^{*}$ & 39 & 31 & 11.5 & 1.1 & 2.1 & 66 & Asthma \\
\hline 347 & 9 & $\sigma$ & 58 & 36 & 9.5 & 1.3 & 2.1 & 70 & Endocarditis \\
\hline 396 & 5 & 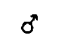 & 34 & 28 & 12.5 & 0.7 & 2.2 & 60 & Incipient tuberculosis \\
\hline 7979 & 7 & $\sigma^{\prime \prime}$ & 47 & 27 & 13 & 3.1 & 1.1 & 55 & Appendicitis \\
\hline 427 & 5 & $\sigma^{\pi}$ & 47 & 33 & 14 & 2.0 & 2.4 & $6 \overline{0}$ & Epilepsy \\
\hline 319 & 4 & 甲 & 34 & 25 & 11.5 & 1.3 & 1.7 & 64 & Pertussis \\
\hline 407 & 8 & $q$ & 38 & 23 & 8 & 1.6 & 1.8 & 60 & Lobar pneumonia \\
\hline 625 & 9 & $q$ & 54 & 26 & 11.5 & 2.0 & 1.8 & 62 & Asthma \\
\hline 361 & 6 & $\sigma^{\pi}$ & 39 & 29 & 11.5 & 1.5 & 2.5 & 64 & Cervical adenitis \\
\hline 740 & 8 & $\sigma^{\prime}$ & 51 & 31 & 9.5 & 2.1 & 1.8 & 65 & Gastro-enteritis \\
\hline 889 & 4 & $\sigma$ & 31 & 26 & 11 & 2.8 & 1.0 & 50 & Epilepsy \\
\hline 708 & 4 & व & 35 & 31 & 12.5 & 1.1 & 0.6 & 50 & Purpura haem. \\
\hline 1058 & 13 & $q$ & 63 & 38 & 12.5 & 1.6 & 1.5 & 60 & Pulmonary tuberculosis \\
\hline 1147 & 9 & $\sigma$ & 59 & 32 & $15 . \overline{5}$ & 2.0 & 1.9 & 65 & Cardiac \\
\hline 1411 & 7 & $\sigma$ & 54 & 30 & 9.0 & 1.6 & 1.1 & 70 & Pulmonary tuberculosis \\
\hline
\end{tabular}

* $\sigma$ denotes male; 9 , female.

content of 40 or even higher does not, in this class of cases, necessarily imply a clinical renal insufficiency. On the other hand, according to Farr and Krumbhaar ${ }^{5}$ the moderate increase rarely seen in presumably normal adults may be due to slight renal involvement not demonstrable by chemical tests.

Urea.-The urea in our series varied between 8 and $21 \mathrm{mg}$. per one hundred c.c. of blood. The average in fifty cases was $12 \mathrm{mg}$. These figures correspond very closely to those given for adults. This also holds true for the relation of urea to total nonprotein nitrogen, which was about 50 per cent.

Uric Acid.-The uric acid in our cases varied between 0.6 and $3.2 \mathrm{mg}$. The average uric acid in fifty cases was $1.8 \mathrm{mg}$. These figures closely parallel those for adults. The highest figure obtained among our cases without renal involvement was $3.2 \mathrm{mg}$., and occurred in a child suffering from muscular rheumatism.

Creatinin.-The creatinin in our series varied between 0.5 and $4 \mathrm{mg}$. The average of all our cases was $1.5 \mathrm{mg}$. These figures correspond with those recorded in adults. Only one case showed a creatinin retention above $2.8 \mathrm{mg}$. This occurred in a boy 5 years of age, with an enormously enlarged colon, and suffering from marked constipation. The creatinin in this case was 4 mg.; the total nonprotein nitrogen, urea, uric acid, as well as the phenolsulphonephthalein test were all within normal limits. Inasmuch as retention of creatinin occurs only in nephritis (Myers and Lough), we are unable to give an explanation for the rather high retention of creatinin observed in this case.

Phenolsulphonephthalein Test.-The total phenolsulphonephthalein excretion for two hours in our cases varied between 50 and 96 per cent., with an average 
of 70 per cent. These figures are in accord with those given for adults ( 50 to 85 per cent.) ; they are, however, slightly lower than those of Tileston and Comfort," who found that the average phenolsulphonephthalein excretion in children was from 78 to 81 per cent.

- DISCUSSION OF TABLE 2: CHILDREN WITH RENAL DISEASE

The cases fall into four groups: (1) acute nephritis; (2) chronic nephritis; (3) passive congestion, and (4) renal neoplasms.

The number of cases (sixteen) is of course too small to permit absolute conclusions to be drawn. As stated above, the chief object of this paper is

TABLE 2.-Analyses of THE BLoon-

\begin{tabular}{|c|c|c|c|c|c|c|c|c|c|c|}
\hline \multirow[b]{2}{*}{ Case } & \multirow[b]{2}{*}{$\begin{array}{l}\text { Age, } \\
\text { Years }\end{array}$} & \multirow[b]{2}{*}{ Sex* } & \multirow[b]{2}{*}{$\begin{array}{l}\text { Weight, } \\
\text { Pounds }\end{array}$} & \multirow[b]{2}{*}{$\begin{array}{c}\text { Non- } \\
\text { protein } \\
\text { N. Mg. } \\
\text { per } \\
100 \text { c.c. }\end{array}$} & \multicolumn{4}{|c|}{ Blood Analysis } & \multicolumn{2}{|c|}{ Urine Analysis } \\
\hline & & & & & $\begin{array}{c}\text { Urea } \\
\text { N, } \\
\text { Mg. } \\
\text { per } \\
100 \text { c.e. }\end{array}$ & $\begin{array}{c}\text { Uric } \\
\text { Acjd, } \\
\text { Mg. } \\
\text { per } \\
100 \text { c.e. }\end{array}$ & $\begin{array}{c}\text { Creat- } \\
\text { inin, } \\
\text { Mg. } \\
\text { per } \\
100 \text { c.c. }\end{array}$ & $\begin{array}{c}\text { Phtha- } \\
\text { lein, } \\
\text { Per } \\
\text { Cent. }\end{array}$ & Sp. Gr. & Albumin \\
\hline 6769 & 7 & 웅 & 43 & 30 & 12.5 & 4.2 & 0.4 & 85 & 1.018 & Large \\
\hline 7863 & 8 & 우 & 44 & 31 & 11.5 & 1.7 & 1.0 & 69 & $\cdots \cdots$ & $\begin{array}{l}\text { Amt. } \\
\text { Large }\end{array}$ \\
\hline 7728 & 4 & q & 31 & 25 & 10.5 & 1.4 & 0.5 & 74 & 1.021 & Moderate \\
\hline 920 & 8 & $\sigma^{\circ}$ & 40 & 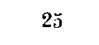 & 10 & 0.7 & 0.6 & 60 & 1.015 & $\begin{array}{l}\text { Amt. } \\
\text { Faint }\end{array}$ \\
\hline 1394 & 2 & q & 24 & 24 & 11.5 & 2.9 & 0.6 & 23 & 1.012 & $\begin{array}{l}\text { trace } \\
\text { Iarge }\end{array}$ \\
\hline 7274 & 9 & 웅 & $781 / 2$ & 41 & 16 & 0.7 & 0.6 & 19 & 1.020 & $\begin{array}{l}\text { Amt. } \\
\text { Large } \\
\text { Amt. }\end{array}$ \\
\hline 8067 & $\varepsilon$ & $0^{2}$ & 23 & $5 ?$ & 23 & 3.6 & 1.2 & 44 & 1.019 & Large \\
\hline H.I.A. & 6 & q & 37 & 47 & 12 & 4.2 & 0.8 & 73 & 1.015 & $\begin{array}{l}\text { Amt. } \\
\text { Trace }\end{array}$ \\
\hline 330 & 8 & 우 & 49 & 34 & 12.5 & 3.5 & 3.3 & 64 & 1.027 & Trace \\
\hline H.I.A. & $25 \mathrm{mos}$. & q & 28 & 41 & 20.5 & 4.0 & 1.1 & 33 & 1.009 & $\begin{array}{c}\text { Large } \\
\text { Amt. }\end{array}$ \\
\hline 540 & $22 \mathrm{mos}$ & 우 & 26 & 37 & 12.5 & 3.1 & 1.7 & 30 & $\ldots .$. & Negative \\
\hline 685 & 9 & $\sigma$ & 64 & 37 & 12 & 1.8 & 1.3 & 58 & 1.023 & Faint \\
\hline 1047 & 7 & 9 & 41 & 26 & 13 & 2.1 & 1.5 & 40 & 1.018 & $\begin{array}{l}\text { trace } \\
\text { Faint }\end{array}$ \\
\hline 783 & 8 & $q$ & 43 & 27 & 13 & 2.7 & 1.5 & 42 & 1.018 & $\begin{array}{l}\text { trace } \\
\text { Faint }\end{array}$ \\
\hline 1136 & 6 & $\sigma^{\prime}$ & $47^{\circ}$ & 26 & 12.5 & 0.8 & 1.7 & 38 & 1.020 & $\begin{array}{c}\text { trace } \\
\text { Large }\end{array}$ \\
\hline 460 & 7 & $\sigma^{\circ}$ & 47 & 35 & 12.5 & 1.7 & 2.4 & 78 & 1.019 & $\begin{array}{l}\text { Amt. } \\
\text { Faint } \\
\text { trace }\end{array}$ \\
\hline
\end{tabular}

* $0^{x}$ denotes male; + , female.

the presentation of normal figures. The detailed study of nephritic cases is now being continued, and will be presented in a future communication.

Acute Nephritis.-The total nonprotein constituents in all the five cases can be considered within normal limits. The phthalein excretion, on the other hand, was diminished. These findings correspond with those noted for adults. Frothingham and Smillie ${ }^{s}$ and others have shown that the phthalein excretion as a rule is diminished in cases of acute nephritis, whereas the total nonprotein constituents are, or may be, normal. As Myers and Lough ${ }^{7}$ express it, "In the early stages of nephritis the phenolsulphonephthalein test probably yields the more valuable information, but after a decided retention has taken place, the nonprotein and urea nitrogen of the blood furnish a much more accurate index of the changes in the condition of the patient." 
Chronic Nephritis.-The five cases of chronic nephritis show an increase in the nonprotein constituents of the blood. With the increased nitrogen retention there was a diminished phenolsulphonephthalein excretion. It has been shown ${ }^{7}$ that in chronic nephritis an increase in uric acid is generally the first evidence of retention. This is clearly demonstrated in our cases. The urea nitrogen is increased next, while large amounts of creatinin in the blood are seen only in cases of severe nephritis. On the other hand, it must be borne in mind that normal nonprotein nitrogen constituents may be present in cases of severe chronic nephritis, even with uremia.

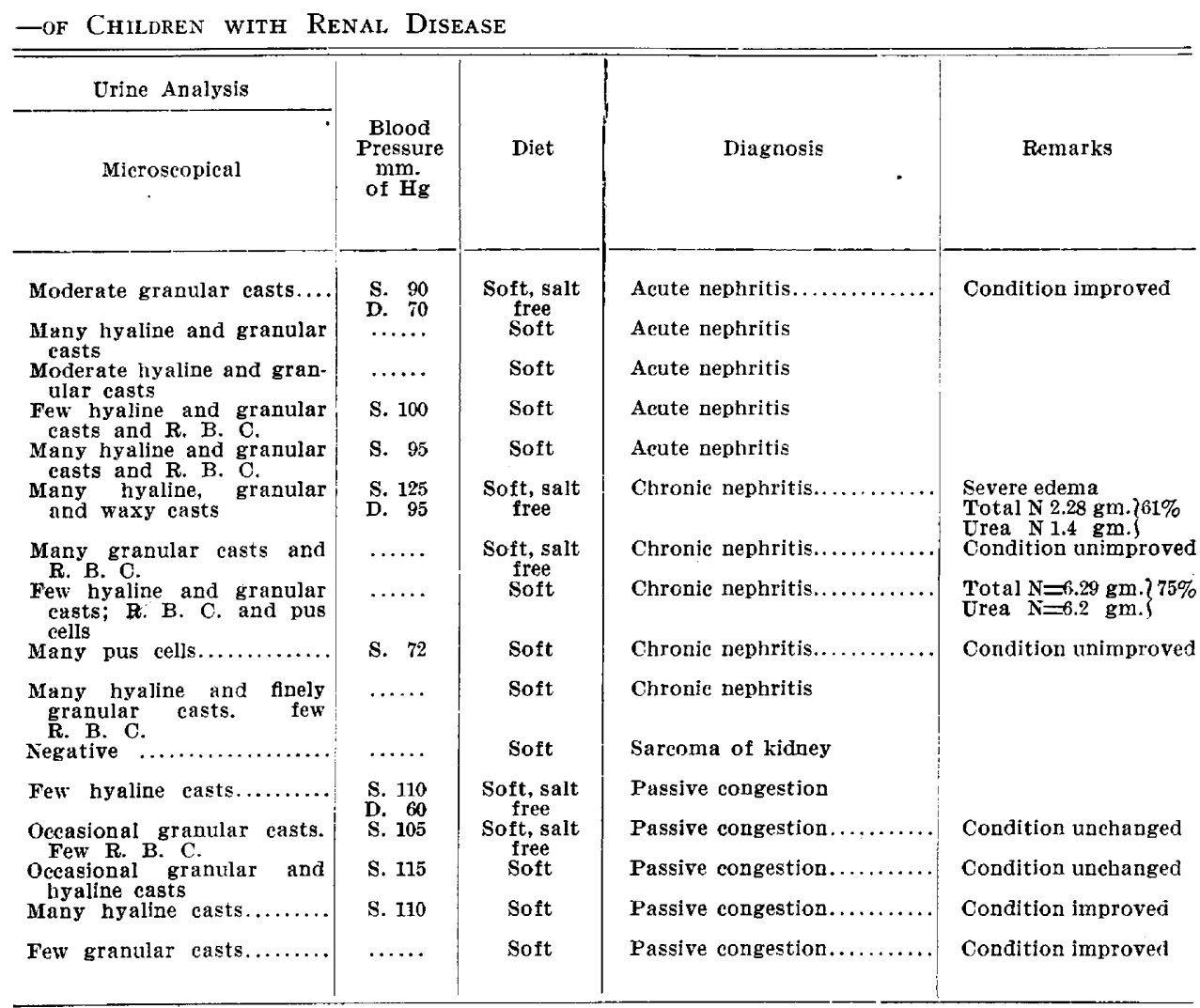

Passive Congestion.-Our five cases of passive congestion showed a practically normal nonprotein nitrogen blood condition. The phenolsulphonephthalein excretion, on the other hand, was decreased, and in some cases markedly so. It would appear that one can at times differentiate cases of chronic nephritis from passive congestion by a chemical examination of the blood alone. In children as in adults, apparently the phenolsulphonephthalein excretion is influenced by passive congestion, but the nonprotein constituents of the blood are not.

Neoplasms.-We have observed one case of sarcoma of the kidney in a child 22 months of age. The urine was normal. The total nonprotein nitrogen was within normal limits. The uric acid was slightly increased. The phenolsulphonephthalein excretion was markedly diminished-30 per cent. in two hours. 
SUMMARY

In a series of fifty children free from evidences of renal disease, chemical examination of the blood gave the following results: the total nonprotein nitrogen varied between 19 and $40 \mathrm{mg}$. per 100 c.c. of blood, the average being $28 \mathrm{mg}$; the urea nitrogen varied between 8 and $21 \mathrm{mg}$, the average being $12 \mathrm{mg}$; the uric acid varied between 0.6 and $3.2 \mathrm{mg}$., the average being $1.8 \mathrm{mg}$.; the creatinin varied between 0.5 and $4 \mathrm{mg}$, the average being $1.5 \mathrm{mg}$; and the phenolsulphonephthalein varied between 50 and 96 per cent., the average being 70 per cent.

A smaller number (16) of cases with renal involvement were examined. Although this series is not large enough for final conclusions, the following hold true for the cases we have studied:

1. In acute nephritis the nonprotein nitrogen constituents were found within normal limits; the phenolsulphonephthalein excretion was diminished.

2. In chronic nephritis the nonprotein nitrogen constituents were usually increased, while the phenolsulphonephthalein excretion was diminished.

3. In passive congestion the nonprotein constituents were normal while the phenolsulphonephthalein was diminished.

4. In one case of sarcoma of the kidney with normal urinary findings the nonprotein constituents, with the exception of uric acid, were normal. The latter was slightly increased. The phenolsulphonephthalein excretion was diminished.

\section{CONCLUSIONS}

1. Figures for the nonprotein constituents of the blood as well as for the phenolsulphonephthalein excretion of children free from renal disease are practically identical with the figures obtained from adults, and vary within the normal limits as the adult figures vary.

2. The changes in these figures in children the subjects of renal disease corresponds, in our cases, with the changes observed in adults.

3. The importance of the tests for diagnosis and prognosis, amply demonstrated in adults, will, in all probability, hold true for children, although a more comprehensive series of cases are required definitely to establish this view.

We wish to express our gratitude to Drs. A. F. Orth and $\mathrm{H}$. Cohn of the house staff of the German Hospital for their assistance.

701 Madison Avenue.

ADDITIONAL REFERENCES

The following additional references may be consulted:

McLean: Jour. Am. Med. Assn., 1913, 1xvi, 415.

Strauss: Ztschr. f. Urol., 1913, vii, 287. 